\title{
MENINGKATKAN PROFESIONALISME PENDIDIK MELALUI SUPERVISI PENDIDIKAN
}

\author{
Elman Ikhtiar Ronaldo Waruwu \\ E-mail : elmanwaruwu@gmail.com
}

\begin{abstract}
Abstrak
Pendidikan merupakan salah satu kebutuhan yang penting bagi manusia. Manusia tidak bisa terlepas dari pendidikan. Oleh karena itu, pendidikan merupakan salah satu sektor penting dalam pembangunan di setiap negara. Namun, pada kenyataannya Pendidikan Indonesia tidak berjalan dengan baik. Hal ini diakibatkan oleh beberapa permasalahan yang terjadi dalam komponenkomponenya. Pada saat ini, salah satu yang menjadi permasalahan dalam dunia Pendidikan Indonesia terletak pada pendidik. Permasalahan tersebut diantaranya ketidak merataan guru dan rendahnya kompetensi guru. Menurut saya ketidak merataan guru dapat diselesaikan dengan cara melakukan pemetaan terhadap guru yang ada sekarang kemudian, melakukan mutasi kepada guruguru yang di daerahnya kelebihan guru ke daerah-daerah yang kekurangan guru. Sedangkan, untuk menyelesaikan rendahnya kompetensi guru dapat diatasi dengan memaksimalkan pelaksanaan supervisi pendidikan ini, niscaya guru-guru di Indonesia akan memiliki kompetensi-kompetensi yang memadai untuk mewujudkan tujuan pendidikan nasional Indonesia.
\end{abstract}

Kata Kunci : Pemecahan Masalah, Pendidik

\section{Latar Belakang}

Pendidikan merupakan salah satu kebutuhan yang penting bagi manusia. Manusia tidak bisa terlepas dari pendidikan. Oleh karena itu, pendidikan merupakan salah satu sektor penting dalam pembangunan di setiap Negara. Indonesia sebagai salah satu negara di dunia juga menjadikan pendidikan sebagai prioritas dalam membangun bangsa. Di dalam Undang-Undang Nomor 20 tahun 2003 tentang Sistem Pendidikan Nasional disebutkan bahwa pendidikan merupakan usaha sadar dan terencana untuk mewujudkan suasana belajar dan proses pembelajaran agar peserta didik secara aktif mengembangkan potensi dirinya untuk memiliki kekuatan spiritual keagamaan, pengendalian diri, kepribadian, kecerdasan, akhlak mulia, serta keterampilan yang diperlukan dirinya.

Selain itu, di dalam Syafril dan Zelhendri Zen (2017:80-81) dikatakan bahwa pendidikan merupakan suatu sistem sosial terbuka. Sebagai suatu sistem, pendidikan memiliki beberapa komponen yang menjadi penggerak sistem tersebut. Komponenkomponen tersebut adalah tujuan, pendidik, peserta didik, materi, metode, media, alat pendidikan dan lingkungan pendidikan. Suatu sistem akan berjalan dengan baik apabila komponen-komponennya baik. Namun, ketika salah satu saja komponen dalam keadaan tidak baik maka sistem tersebut tidak dapat berjalan dengan baik dan hal ini juga terjadi dalam pendidikan. 
Setiap sistem yang dibuat pasti diharapkan dapat berjalan dengan lancar. Namun, pada kenyataannya Pendidikan Indonesia tidak berjalan dengan baik. Hal ini diakibatkan oleh beberapa permasalahan yang terjadi dalam komponen-komponenya. Pada saat ini, salah satu yang menjadi permasalahan dalam dunia Pendidikan Indonesia terletak pada pendidik. Permasalahan tersebut diantaranya ketidak merataan guru dan rendahnya kompetensi guru. Oleh karena itu, penulis mencoba mengkaji cara untuk mengatasi permasalahan di atas. Dari latar belakang ini, dapat dirumuskan suatu permasalahan yakni "Bagaimana cara mengatasi permasalahan dalam Pendidikan Indonesia khususnya yang terjadi pada tenaga pendidik?" Tujuan dari penulisan artikel adalah untuk mengkaji solusi-solusi yang dapat diterapkan dalam Pendidikan Indonesia untuk mengatasi berbagai permasalahan yang terjadi pada tenaga pendidik.

\section{Pembahasan}

Pemerataan

Salah satu yang menjadi permasalahan adalah ketidak merataan pendidik di seluruh Indonesia. Ada kesenjangan jumlah guru di daerah-daerah di Indonesia. Ada daerah yang kelebihan guru sedangkan, ada daerah yang kekurangan guru. Apabila hal ini tidak diatasi maka, akan terjadi kesenjangan dalam kualitas pelayanan siswa di daerah-daerah yang ada di Indonesia sehingga peserta didik di setiap daerah tidak memiliki kempampuan yang setara. Menurut saya, hal ini dapat diselesaikan dengan cara melakukan pemetaan terhadap guru yang ada sekarang kemudian, melakukan mutasi kepada guruguru yang di daerahnya kelebihan guru ke daerah-daerah yang kekurangan guru. Selain itu, juga dapat dilakukan perekrutan guru di daerah-daerah yang kekurangan guru dengan jumlah formasi yang

\section{Kompetensi Guru}

Setiap guru dituntut untuk menguasai 4 kompetensi yakni Pedagogik, Kepribadian, Profesional, dan Sosial. Keempat kompetensi ini, harus dimiliki oleh seorang guru karena hal ini sangat mempengaruhi hasil pembelajaran. Apabila seorang guru tidak menguasai salah satu dari keempat kompetensi ini maka, pembelajaran akan menjadi tidak berhasil. Hal ini merupakan suatu masalah bagi dunia pendidika yang menghambat jalannya Sistem Pendidikan Indonesia.

Permasalahan ini dapat diatasi dengan memaksimalkan pelaksanaan supervisi pendidikan di Indonesia. Supervisi pendidikan merupakan suatu proses pemberian layanan dalam visi misi untuk mencapai tujuan pendidikan melalui peningkatan kinerja guru baik secara individual atau kelompok. Menurut Sabandi (2013:3), Supervisi Pendidikan sekarang ini 
berbentuk kolaborasi antara supervisor dan guru secara bersama sama untuk meningkatkan kualitas dari Pembelajaran dan juga menumbuhkan budaya belajar pada guru untuk meningkatkan kompetensinya.

Supervisi pendidikan dilakukan dengan beberapa tahap yakni :

1.Pengumpulan data

2.Penilaian

3. Mendeteksi kelemahan

4. Memerbaiki kelemahan

5. Bimbingan dan pengembangan

Dalam pelaksanaan supervisi pendidikan, supervisor akan melakukan observasi terhadap guru yang menjadi target dari supervisi. Selanjutnya, supervisor akan mendeteksi kelemahan yang dimiliki oleh guru tersebut. Sebagai tindak lanjut dari temuan tersebut, maka dilakukan pembinaan dan bimbingan kepada guru tersebut untuk memperbaiki kelemahannya yang dimilikinya serta mengembangkan kompetensi yang dimilikinya. Dengan memaksimalkan pelaksanaan supervise pendidikan ini, niscaya guru-guru di Indonesia akan memiliki kompetensi-kompetensi yang memadai untuk mewujudkan tujuan pendidikan nasional Indonesia.

Selain itu, juga dapat dilakukan pembinaan dan bimbingan kepada calon guru ditingkat pada masa perkuliahan di perguruan tinggi masing-masing. Calon-calon guru dituntun untuk membangun kompetensinya sedini mungkin dan semaksimal mungkin sehingga pada saat terjun ke lapangan, caloncalon guru tersebut sudah memiliki ataupun menguasai kompetensi kompetensi yang diharapkan dimiliki oleh seorang guru.

Kesimpulan dan Saran

Permasalahan yang terjadi dalam dunia pendidikan antara lain adalah ketidak merataan pendidik dan juga rendanya kompetensi pendidik. Kedua permasalahan ini dapat diatasi dengan melakukan pemetaan terhadap guru guru yang ada dan juga memaksimalkan pelaksanaan Supervisi Pendidikan.

Penulis menyarankan agar permasalahan ini dapat diselesaikan secepat mungkin sehingga Pendidikan Indonesia dapat semakin membaik sera tidak tertinggal dari pendidikan negera lain.

\section{Referensi}

Undang-Undang Republik Indonesia No. 20 Tahun 2003.

Syafril \& Zelhendri Zen. 2017. Dasar-Dasar Ilmu Pendidikan. Padang : UNP Press. Sabandi, A. (2013). Supervisi Pendidikan Untuk Pengembangan Profesionalitas Guru Berkelanjutan. Pedagogi, Jurnal Ilmiah Ilmu Pendidikan, XIII (2), 1-9. 